Izabela Morska

Uniwersytet Gdański

(iD http://orcid.org/0000-0002-6772-069X

\title{
Blizna po solidarności Polski ruch antyłowiecki w świetle tradycji XIX-wiecznej ekologii i praktyki nieposłuszeństwa obywatelskiego
}

\author{
The Scar over Solidarity \\ Polish Anti-hunting Movement as the Successor of \\ the Nineteenth-century Nature Conservation Movement \\ and Civil Disobedience Practice
}

\begin{abstract}
The dispute between the supporters of hunting and its opponents in the fall 2019 and winter of 2020 concerned the management of public goods. Its development took the shape of a kind of war maneuvers which, along with the tightening of the screw, as subsequent bans followed, could turn into a replica of a civil war. This, however, was hindered by the pandemic. Thus, the anti-hunting movement, which was gaining more and more popularity among regular citizens for whom strolls in the forest become the first exposure to public activism, practically ceased to exist. Was the movement a foreign implant, as its adversaries implied? This essay assumes that the anti-hunting movement was both an altruistic and educational project, based on solidarity and empathy, as well as the willingness to sacrifice one's comfort for the benefit of others, in this case - forest animals which are shot at metonymically, instead of the citizens practicing public disobedience against whom it is still inappropriate to lead an open war.
\end{abstract}

Key words: hunting, tradition, ecology, conscience, civil disobedience

Streszczenie: Spór pomiędzy zwolennikami myślistwa oraz jego przeciwnikami z jesieni 2019 i zimy 2020 roku dotyczył zarządzania dobrami publicznymi. Jego rozwój przybrał kształt swego rodzaju manewrów wojennych, które wraz z ku- 
mulowaniem się kolejnych zakazów mogły przekształcić się w replikę wojny domowej. Przeszkodził temu rozwój pandemii. Tym samym ruch antyłowiecki, zdobywający sobie coraz większą popularność wśród ludzi, dla których leśne spacery stały się pierwszym w życiu doświadczeniem aktywizmu, praktycznie przestał istnieć. Czy był zatem obcym implantem, jak sugerowały głosy mu przeciwne? Autorka tego eseju zakłada, że ruch antymyśliwski był projektem zarówno altruistycznym, jak i edukacyjnym, który za podstawę postawił sobie solidarność i empatię oraz gotowość do poświęceń na rzecz innych, w tym wypadku - leśnych zwierząt, do których strzela się metonimicznie, w zastępstwie obywateli praktykujących nieposłuszeństwo obywatelskie, z którymi wciąż nie wypada prowadzić otwartej wojny.

Słowa kluczowe: myślistwo, tradycja, ekologia, sumienie, nieposłuszeństwo obywatelskie

\section{Która tradycja jest nasza}

Czytając informacje na temat współczesnych reakcji na ruch praw zwierząt i wypowiedzi ze strony rządowej (Ministerstwa Środowiska) z jednej strony oraz reprezentantów ortodoksyjnego katolicyzmu z drugiej ${ }^{1}$, uderza wpierw to, że wrażliwość na ekologię odbierana jest jako niebezpieczna nowinka, choć na ziemiach polskich działania na rzecz ochrony przyrody znalazły sobie wielu światłych przedstawicieli już w wieku XIX, niemal równolegle z ruchem na rzecz konserwacji natury w USA ${ }^{2}$. Były po temu powody. Jak czytamy w Historii kultury materialnej Polski, „na początku XIX w. lesistość Królestwa szacowano na ok. 30\% ogólnej powierzchni, a w 1909 r. [...] tylko na 18,7\%"3. Wycinki lasów już w wieku XIX wzbudzały niepokój, gdyż postrzegane były jako zagrożenie „polskości kraj-

${ }^{1}$ Używam tu terminu ortodoksja, gdyż polski katolicyzm zdaje się oddalać od katolicyzmu empatycznego, z jednej strony konsekwentnie prezentując niezgodę na empatię, z drugiej strony - nie stawiając tamy skłonności do potępień. W rezultacie polski katolicyzm ma się do katolicyzmu praktykowanego w Watykanie, w Londynie czy w bazylice misyjnej w Carmel (Kalifornia) mniej więcej tak, jak sekty Satmar z Brooklynu i Haredi z dzielnicy Mea Shearim w Jerozolimie mają się do judaizmu postępowego czy nawet konserwatywnego.

2 Por. American Conservationism Timeline. https://www.nps.gov/mabi/learn/hi storyculture/conservation-timeline-1801-1900.htm [dostęp: 24.09.2020].

${ }^{3}$ Historia kultury materialnej Polski. T. 5: Od 1795 do 1870 roku. Red. W. Hensel, J. Pazdura. Wrocław 1978, s. 17. Cyt. za: B. Мүтүсн: Poetyka i łowy. O idei dawnego polowania w literaturze polskiej XIX wieku. Katowice 2004, s. 23. 
obrazu $^{\prime \prime 4}$. Do traktowania lasów jak plantacji drewna (w ten sposób szybko zniszczono gatunkową różnorodność niższych rejonów Tatr) należy doliczyć osuszanie bagien i niszczenie torfowisk, a tym samym redukcję siedlisk ptaków i zwierząt. Romantyczna nostalgia (zmniejszanie się kompleksów leśnych odnotowane w inwokacji do księgi czwartej Pana Tadeusza) dodatkowo uwrażliwiała na szkody czynione naturze. Od połowy XIX wieku patriotyzm realizował się w działaniach na rzecz zagrożonych gatunków i ochrony przyrody ${ }^{5}$.

Działania te mogły rozwinąć się zwłaszcza pod zaborem austriackim, gdyż tam aktywność na rzecz ochrony krajobrazu skupiła się wokół utworzenia Tatrzańskiego Parku Narodowego ${ }^{6}$. Pod wpływem polskich miłośników natury Władysław Zamoyski zakupił na licytacji zniszczone dobra zakopiańskie i zainwestował w zalesienie zdewastowanych terenów. W międzywojniu Państwowa Rada Ochrony Przyrody nie zdołała doprowadzić do powstania w tym miejscu parku narodowego, ale nastąiłiło to w roku 1954, kiedy Tatry znów były zdewastowane. Także i dziś parki narodowe okazują się zagrożone - czy to przez wspieranych rozmaitymi układami deweloperów, czy w wyniku działalności Lasów Państwowych.

Warto wspomnieć o powtarzającym się usprawiedliwieniu owych dewastacji. To niemieccy faszyści urządzili $w$ Tatrach masowy wyrąb lasów ${ }^{7}$. To brytyjska spółka Century European Timber Corporation, która dokonała wycinki poza kontraktem, spustoszyła

${ }^{4}$ Ibidem.

${ }^{5}$ J. Kolbuszewski: Ochrona przyrody a kultura. Warszawa 1990, s. 40-41, 57. Cyt. za: B. Мүтүсн: Poetyka i łowy..., s. 24.

${ }^{6}$ W. Szafer: Tatrzański Park Narodowy. Kraków 1962.

7 Por. zwięzłą opinię o zarządzie lasów w Polsce przed 1939 rokiem, którą wystawił Kurd Eissfeldt, tuż przed przyjęciem funkcji kierownika Wydziału Lasów Urzędu Gubernatora Generalnego i kierownika Wydziału Głównego Lasów w tzw. rządzie GG, od 29 października 1939 roku, przytoczoną w dzienniku Hansa Franka: „Polacy nie prowadzili zachowawczej gospodarki drewnem, lecz wycinali całe drzewo użytkowe. Prawie w ogóle nie zachowały się stare drzewa. Dwie trzecie lasów znajduje się w rękach prywatnych i jest w dużym stopniu wykarczowane. Wcześniej Polska eksportowała drewno; w dłuższej perspektywie jednak Generalne Gubernatorstwo stanie się obszarem wymagającym dotacji do drewna. W odpowiednich do tego okolicach zostaną stworzone wielkie obozy pracy" (Cyt. za: Rok 1939 w dzienniku Hansa Franka. Przeł. W. Grotowicz. Wstęp i oprac. P. Kosıński. Warszawa 2019, s. 40-21). Eissfeldt wspomina też o masowej nielegalnej wycince drzew przez okolicznych chłopów (ibidem, s. 40). Okupant posługuje się językiem przymusu i nadzoru, jednak za cel, przynajmniej wstępnie, stawia sobie nie eksploatację, lecz naprawę szkód. 
Puszczę Białowieską. Ale gdyby ta spółka działała tylko w ramach kontraktu, który zawarła z rządem polskim na lata 1924-1934, to sprawa i tak skończyłaby się dewastacją (spółka dostała koncesję na wyrąb 7,2 mln $\mathrm{m}^{3}$ drewna nad Niemnem i w Puszczy Białowieskiej, w tym w samej puszczy $4 \mathrm{mln} \mathrm{m}^{3}$; ogólnie planowano wyciąć 20 tys. hektarów). Firma, wbrew umowie, nie prowadziła jednak zalesiania i usuwała najbardziej wartościowe drzewa. Co gorsza, nie wywoziła polskiego drewna za granicę, lecz odsprzedawała z zyskiem koncesje firmom zagranicznym i krajowym. Drewno pozostawało w Polsce i przeznaczano je na klepkę, podkłady kolejowe i gonty, co skutkowało spadkiem jego wartości. Zarządzanie wycinką wyglądało trochę jak w opowiadaniu The Outpost of Progress Josepha Conrada. Nieudolni dyrektorzy zmieniali się z dnia na dzień, robotnicy pobierali wypłatę $\mathrm{w}$ naturze, a rozmaici biznesmeni, nie mając pojęcia o kupowanym rodzaju drewna, przeznaczali najcenniejsze sortymenty na opał. Pod wpływem opinii publicznej rząd polski zerwał umowę z brytyjską firmą w 1929 roku, wypłacając sumę 375 funtów szterlingów jako rekompensatę za jej unieważnienie ${ }^{8}$. Gdyby takiego kroku nie podjęto, wycinka w puszczy musiałaby zostać wstrzymana do czasu sądowego rozstrzygnięcia sporu. Jak pisze Simona Kossak:

Odrodzone państwo polskie znakomicie poradziło sobie bez Century i obcych kapitałów. Rozmiar rocznego pozyskania nie tylko nie zmniejszył się, lecz w latach 1929-1932 udało się o dwadzieścia trzy procent pobić dziejowe rekordy ustanowione przez Niemców i Anglików ${ }^{9}$.

O tym, że trend wykorzystywania zasobów naturalnych do przetrwania jest niejako wpisany $\mathrm{w}$ niezbyt skuteczne zarządzanie państwem, pokazują wczesne decyzje sejmowe Księstwa Warszawskiego, cytowane przez Wacława Tokarza w Dziejach Polski 1816-1831. W porównaniu do jego Wojny polsko-rosyjskiej 1830 i 1831 jest to lektura o wiele bardziej przygnębiająca i pewnie dlatego niewznawiana po 1931 roku. Po epizodzie napoleońskim Księstwo Warszawskie stało się dla Polaków szansą na pokazanie, czy potrafią wybić się na niepodległość nie za pomocą szabli, lecz rozwoju gospodarczego; nowoczesna Europa wszak się mobilizowała, aby stać się żywym dowodem, iż postęp jest przyczynkiem do osiągnięcia powszechnego

8 Por. S. Kossak: Saga Puszczy Białowieskiej. Warszawa 2016, s. 322-326.

${ }^{9}$ Ibidem, s. 326. 
szczęścia ${ }^{10}$. Polacy mieli okazję, by pokazać, że są czymś więcej niż zbiorowiskiem warchołów na sejmikach, wybierających sobie na władców obcych książąt. Mogli udowodnić, że nie poprą jakiegoś kolejnego dyktatora w mundurze, typu Napoleon, który będzie miał fantazję, żeby zapanować nad Europą lub też, dla odmiany, że przez własną nieudolność nie otworzą się na inwazję jakiegoś wschodniego imperium.

Zwykli mieszkańcy ziem polskich byli zresztą tak samo zmęczeni polityczną euforią jak paryżanie rewolucją i dyktaturą napoleońską. „Na ogół miasto i lud - cytuje Tokarz dobrze poinformowanego obserwatora austryjackiego - robią wrażenie narodu wyczerpanego przejawami entuzjazmu i siły [...]. Wszyscy tęsknią do spokoju i wytchnienia"11. Z ludźmi zmęczonymi euforią pracuje się skutecznie i w spokoju. Nie było bowiem jeszcze przejawów społecznej depresji. Te przyjdą później, kiedy tym ludziom zafundowane zostanie powstanie listopadowe. Dekadę wcześniej rozwój gospodarczy w zakresie rolnictwa wyglądał tak:

Po stosunkowo pomyślnym roku 1818, gdy to z Gdańska wywieziono 17.923 łasztów pszenicy, 3.174 żyta, 70.000 sztuk drewna, dzięki czemu wpłynęło do kraju 27 miljonów złotych, przyszły cła zbożowe w Anglji i katastrofalny spadek cen. Produkcja zboża, które nie mogło znaleźć odbytu na bardzo szczupłym rynku wewnętrznym, przestała się opłacać. Większa własność, zadłużona przeważnie po uszy jeszcze z czasów pruskich, utrzymująca się w posiadaniu majątków jedynie dzięki przedłużanemu wciąż moratorium, wyczerpana przez wojny Księstwa i rozpaczliwą okupację rosyjską, znajdowała się w położeniu bez wyjścia. Zaledwie tu i ówdzie próbowała uciec od produkcji zbóż, przerzucić się na hodowlę owiec i bydła, uprawę roślin pastewnych, uprawę ziemniaków i gorzelnictwo; próby meljoryzacji i zaprowadzenia płodozmianu należały do bardzo nielicznych. Kryzys tej warstwy społecznej stawał się kryzysem całego Królestwa ${ }^{12}$.

Czyń sobie ziemię poddaną. A chłopi?

W jeszcze gorszym położeniu znaleźli się włościanie. Sprzedaż zboża wystarczała im zaledwie na pokrycie części podatków;

${ }^{10}$ Praktyka - utopia - metafora. Wynalazek w XIX wieku. Red. J. KuвICKA, M. LiTwinowicz-DroźDZiel. Warszawa 2016.

${ }^{11}$ W. Tokarz: Dzieje Polski 1816-1831. Warszawa 1930, s. 99.

${ }^{12}$ Ibidem, s. 102. 
drobne, lokalne nieurodzaje prowadziły do katastrof, które wymagały interwencji i pomocy rządu. Niedola ich zwracała wtedy na siebie uwagę powszechną, odbijała się głośnym echem w sej$\operatorname{mach}^{13}$.

Ostatecznie wstrzymano reformę uwłaszczeniową: „zdecydował o tem prawdopodobnie wzgląd na konserwatywną Rosję, w której położenie włościan było fatalne; liczono się również $\mathrm{z}$ bardzo ciężkiem położeniem naszej własności wielkiej"14. W rzeczy samej, powstrzymano się przed nią także w 1831 roku, kiedy to tylko przyciągnięcie chłopów mogłoby przeważyć szalę zwycięstwa na rzecz Królestwa Polskiego, gdyby ogłoszono pospolite ruszenie najpóźniej $\mathrm{w}$ marcu, a nie w czerwcu, kiedy zaczęły się prace $\mathrm{w}$ polu, a chłopom - jak pisze Adam Leszczyński - inaczej niż w powstaniu kościuszkowskim - „nie zmniejszono nawet wymiaru pańszczyzny"15. Kiedy chodziło o własne interesy, a dokładnie o utrzymanie pańszczyzny, to wolno było się przejmować tym, co myśli Rosja, a nawet brać z niej przykład.

We wszelkich innych kwestiach przybliżać się do Rosji nie było stosownie. Dlatego msze dla związanych pańszczyzną chłopów, $\mathrm{w}$ większości niepiśmiennych (projekt szkolnictwa podstawowego upadł w sejmie, bo szkolnictwo miało kosztować $7 \mathrm{mln}$ zł, czyli jedną czwartą dochodu państwa pochodzącego z wywozu drewna a w dodatku upadłby protekcjonalny argument, o którym wspomina Leszczyński, iż chłopów „trzeba najpierw ukształcić i wychować”16), miały nadal odbywać się po łacinie, ponieważ nabożeństwo w ojczystym języku zanadto zbliżyłoby obrządek w kościele polskim do kościoła rosyjskiego. Sprawy obyczajowe miały bowiem dla sejmu Księstwa Warszawskiego ogromne znaczenie. Na pierwszym sejmie w roku 1818 dyskutowano więc gorąco nad ustawą, która anulowała prawo do rozwodów (gwarantowane przez Kodeks Napoleona). A kiedy już tym się zajęto, to $\mathrm{w}$ drugiej kolejności podjęto pewne próby rozwinięcia wydobycia węgla, poszukiwania soli, produkcji żelaza, cynku, blach cynkowych i żelaznych, wyrobu kos i sierpów ${ }^{17}$. Wszelkie starania rozdzielenia Kościoła od państwa (jak wyżej wspomniane prawo do rozwodów, jak kwestie edukacji), zgodnie z tym, co notuje Tokarz, rykoszetowały.

\footnotetext{
${ }^{13}$ Ibidem.

${ }^{14}$ Ibidem.

15 A. Leszczyński: Ludowa historia Polski. Warszawa 2020, s. 303.

${ }^{16}$ Ibidem, s. 301.

17 W. Tokarz: Dzieje Polski..., s. 102.
} 
Wielka własność pozostała przy tym nietykalna, mogła więc nadal korzystać z bezpłatnej pracy chłopów, jakkolwiek oparta na wyzysku ziemi (brak płodozmianu) i ludzi (pańszczyzna) gospodarka przestaje się opłacać. Posiadacze wielkich majątków upierali się jednak przy pańszczyźnie (jej zniesienie tuż po upadku powstania listopadowego uważane jest za carską represję; pańszczyznę też popiera Kościół w obawie, że wolni chłopi zaczną przechodzić na prawosławie). Żyć na wysokiej stopie można było nadal, bo na podorędziu zawsze był jakiś las. Od pośrednika drewno kupowały cukrownie (z Wielkopolski i Małopolski), huty (z południa i zaboru pruskiego), papiernie, a także przedsiębiorstwa kolejowe (z przeznaczeniem na podkłady kolejowe). Zatem tradycja rozmieniania zasobów naturalnych na "gotowy grosz" jest naszą własną, choć w wieku XIX jeszcze nikt nie nazywał tego patriotyzmem. Przykrywało się ją natomiast mitem o własnym cierpiętnictwie.

Ochrona zagrożonych gatunków i pejzaży jest wpisana w tradycję polską od połowy XIX wieku. Miała ona polegać na budzeniu świadomości i przeciwdziałaniu bezmyślnej eksploatacji. Nowoczesne podejście do przyrody od połowy XIX wieku nakierowane jest na dobro gatunku (ochronę przed wyginięciem) - tym się różni od staropolskich gestów panów feudalnych, którzy zabezpieczali pewne gatunki po to, żeby następnie na nie polować. Aktywność na rzecz środowiska naturalnego była też działaniem zbiorowym, łączącym ludzi o rozmaitej proweniencji: przyrodników i nawróconych na miłość do natury mieszczan, arystokratów oraz byłych kłusowników, którzy następnie wsławili się jako tatrzańscy przewodnicy - jak Maciej Sieczka, pracujący wspólnie z Janem Gwalbertem Pawlikowskim, encyklopedystą, taternikiem i jednym z pionierów ochrony przyrody.

Współczesne wymazywanie tej tradycji - zadziwia. Nie chodzi tu bowiem o odległe czasy sprzed wynalazku druku, lecz o okres niezbyt odległy i solidnie udokumentowany. Widać, jak łatwo udaje się przestawić punkty ciężkości. I tak, niecałe dwieście lat później, ochrona przyrody przestaje być aktem patriotycznym, a staje się czymś wprost przeciwnym, wrogiem polskości, aktem zasługującym na potępienie. Bo też obecny polski rząd i jego przedsiębiorstwo Lasy Państwowe wycinają drzewa na potęgę. Statystyki są porównywalne z najgorszymi momentami wyrębu lasów w ciągu ostatnich dwustu lat $^{18}$. Protesty intelektualistów zdają się na niewiele. Od trzydziestu

18 A. WAJRAK: „Polska rżnie lasy, aż wióry leca". "Gazeta Wyborcza”, 7 lipca 2020. https://wyborcza.pl/7,75400,26104840,polska-rznie-lasy-az-wiory-leca.html [dostęp: 10.07.2020]. 
lat niszczenie natury jest działaniem wspieranym już nie przez obcą, lecz przez polską władzę.

\section{Sumienie jak busola}

Sumienie społeczne przełomu XX i XXI wieku zostaje ukonkretnione i ukontekstowione. Łacińska nazwa conscientia to połączenie dwóch wyrazów: con - 'z', oraz scientia - 'wiedza'. Jej echo usłyszymy w niemieckim Bewusstsein ('świadomość') i Gewissen ('sumienie')" $)^{19}$. Klaudia Koonz podkreśla, że sumienie łączy w sobie elementy tożsamości, świadomości i idealizmu. W Nazistowskim sumieniu (książce nieprzetłumaczonej na język polski, choć potrzebnej) wskazuje, jak w latach poprzedzających II wojnę światową wychowywano przyszłych zabójców, kształtując ich sumienia na bazie etnicznej dumy, rasowej higieny, narodowego fundamentalizmu i alienowania współobywateli, którzy nie byli szczególnie liczni (niemieccy Żydzi stanowili mniej niż 1\% mieszkańców Rzeszy ${ }^{20}$. Wpływano na nich za pomocą masowych publikacji, badań naukowych, sztuki, filmów dokumentalnych i satyry. Pokolenie, które zostało oduczone współczucia, stało się gotowe, żeby zabijać. Pomimo oparcia w postaci dziesięciorga przykazań sumienie $\mathrm{w}$ tradycji judeochrześcijańskiej okazuje się nie tyle trwałe, ile umowne, zależne od konwencji, ulegające kształtowaniu. Niejednokrotnie decydujące okazują się wyjątki, którymi objęci zostają wszyscy nienależący do społeczności lub z niej wykluczeni.

Połączenie tożsamości, świadomości i idealizmu okazuje się mieszanką wybuchową. Zwłaszcza jeśli zabraknie wiedzy. Inną opcją jest droga indywidualna, która wyklucza społeczną przypadkowość. Jak wskazuje filozof i etyk Bachia ben Josef ibn Pakuda ${ }^{21}$, naszym zadaniem jest nieustająca samoinwigilacja (bo Bóg i tak wie: „Duch człowieka jest pochodnią Pana, która bada wszelkie skrytości wnętrza", Prz 20,2722). Oś czynów i jej filary zbudowane są bowiem na intencji i głosie sumienia, który jest zarazem wewnętrzną mądrością

19 Por. C. Koonz: The Nazi Conscience. Cambridge 2003.

${ }^{20}$ Eadem: How the Nazis Made Anti-Semitism Respectable. https://www.youtu be.com/watch?v=usL9bmrnQRk [dostęp: 12.07.2020].

${ }^{21}$ Chodzi o dzieło Torat Chowot ha-Lewawo (Nauka obowiąków serca). https:// www.jhi.pl/psj/Bachia_ben_Josef_ibn_Pakuda_(Bakoda) [dostęp: 12.07.2020].

${ }^{22}$ Biblia Gdańska (2017). http://bibliepolskie.pl/zzteksty_vers_por.php?txid=29 [dostęp: 2.03.2021]. 
i busolą (mądrość pomoże nam powstrzymać się od pewnych działań, a busola wskazuje kierunek ruchu). Nieustająca samoinwigilacja jest potrzebna, abyśmy nie skalali własnego sumienia (bo zacznie pokazywać fałszywy kierunek). Jeśli połączyć myśl Bachii z badaniami Klaudii Koonz, to wolno założyć, że sumienie może niestety zostać splugawione $\mathrm{w}$ procesie wychowania indywidualnego lub całego narodu - poprzez odjęcie elementu empatii i naukę czerpania radości z zabijania.

Nosząc w pamięci doświadczenie Zagłady i rwandyjskiego ludobójstwa, nie obronimy konstruktu sumienia jako surowego oka boskiej sprawiedliwości, które $\mathrm{w}$ stosownych momentach odzywa się i nas oskarża. A im bardziej sumienie zawłaszczane jest przez dyskurs religijny, tym łatwiej dostrzec, że podlega ono zróżnicowaniu, że pogląd judaizmu na sprawę aborcji zasadniczo różni się od spojrzenia chrześcijańskiego, a poglądy człowieka wychowanego $\mathrm{w}$ hinduizmie różnić się będą - w odniesieniu do praw zwierząt - od poglądów wyznawcy konfucjanizmu. Nie ma jednolitego ludzkiego sumienia; jest wiele jego wersji. W rezultacie triada: wiara - poglądy - sumienie, okazuje się niestabilna, ruchoma. Bo też co czynić, jeśli nie oskarża? Jeśli nasza psychika, gdyby ją przebadać, na skali samozadowolenia umieszcza się blisko psychopatii? Lub jeśli nie mamy ochoty się dokształcać i zamiast con scientia dorabiamy się absque scientia, jeśli należymy do grupy $62 \%$, które nie przeczytało w zeszłym roku żadnej książki²3, jeśli sami pozbawiamy się przesłanek, na których sumienie mogłoby się pożywić, aby się stać mądrością wewnętrzną. Wtedy zostaje nam nie tyle marność, ile mierność.

O nieznośnej relatywności sumienia pisze Hannah Arendt w eseju Niepostuszeństwo obywatelskie. Spór między obywatelem a prawem niesłusznym prawem - wywodzi filozofka od Henry'ego Davida Thoreau: „Thoreau bronił swej sprawy nie na gruncie moralnej relacji między obywatelem a prawem, lecz na gruncie sumienia jednostki i moralnego obowiązku sumienia"24. Thoreau nie oczekuje od swych bliźnich, by wszyscy angażowali się w polityczny opór. "Jest rzeczą samą przez się zrozumiałą, że człowiek nie ma obowiązku się poświęcać wykorzenianiu jakiegokolwiek, nawet największego, zła - pisze - ale zobowiązany jest przynajmniej... nie wspierać go

${ }^{23}$ 38\% Polaków czyta książki. https://www.bn.org.pl/w-bibliotece/3413-38\%25polakow-czyta-ksiazki.html [dostęp: 15.07.2020].

${ }^{24}$ H. Arendt: O przemocy. Niepostuszeństwo obywatelskie. Przeł. A. ŁagodzKa, W. Madej. Warszawa 1999, s. 151. 
w praktyce" ${ }^{\prime 25}$. Zło zostaje ukontekstowione. Dla Thoreau złem było zaangażowanie się jego kraju w wojnę z Meksykiem w celu poszerzenia terytorium i praktykowanie niewolnictwa.

Zasady sumienia, zauważa Arendt, czy wyraża je Sokrates, czy Thoreau, mają „całkowicie negatywny charakter. Nie mówią, co robić; mówią jedynie, czego nie robić" ${ }^{\prime 26}$. Bo inaczej trudno nam będzie samym ze sobą żyć. „Nie formułują określonych zasad dla podjęcia działania; wyznaczają granice, których nie powinien przekraczać żaden czyn. Mówią: nie czyń źle, bo będziesz musiał żyć razem ze złoczyńcą" ${ }^{27}$. Już Platon za Sokratesem określa „myślenie jako bezgłośny dialog pomiędzy mną i moim ja; z egzystencjalnego punktu widzenia dialog ten, podobnie jak wszystkie inne dialogi, wymaga, by partnerzy byli przyjaciółmi" 28 . Jest to też samoinwigilacja, ale dialogowa. Obowiązkiem obywatelskim staje się więc nie tylko posiadanie wrodzonej zdolności rozróżniania dobra i zła, ale też zainteresowanie sobą ${ }^{29}$. W przełożeniu na współczesny nam kontekst, jest to pozycjonowanie siebie jako jednostki obywatelskiej, którą stajemy się, popierając pożyteczne działania, biorąc udział w protestach lub nakładając znaczącą obwódkę na zdjęcie profilowe w mediach społecznościowych. Konsekwencją owego zainteresowania sobą okazuje się bowiem działanie pozytywne, wynikające z założenia, że nasza opinia ma znaczenie, gdyż może kogoś przekonać, zniechęcić lub przeważyć szalę.

Tu jednak zaczyna się nieunikniony relatywizm - to bowiem, „z czym ja nie mogę żyć, może nie niepokoić sumienia innego człowieka" [podkr. - I.M.]"30. W sytuacji spornej jedno sumienie konfrontuje się z drugim. Gubernator Missisippi Ross Barnett działa bowiem $\mathrm{w}$ zgodzie $\mathrm{z}$ własnym sumieniem, wierzy w swą sprawę równie głęboko jak Martin Luther King - i jest gotów pójść za nią do więzienia ${ }^{31}$. Media społecznościowe egzemplifikują podobne konflikty sumień przełożonych na opinie, gdyż formuła bycia dobrym obywatelem opiera się na widoczności; w ujęciu Arendt dobry obywatel nie jest populistą (to przyjdzie później), lecz jest częścią

${ }^{25}$ H.D. Thoreau: Obywatelskie niepostuszeństwo. W: Idem: Życie bez zasad: eseje. Wybrała, przeł., przedmową i przypisami opatrzyła H. Cieplińska. Warszawa 1983, s. 207. Cyt. za: H. Arendt: O przemocy..., s. 151-152.

${ }^{26}$ H. Arendt: O przemocy..., s. 156.

${ }^{27}$ Ibidem.

${ }^{28}$ Ibidem.

${ }^{29}$ Ibidem, s. 157.

${ }^{30}$ Ibidem.

${ }^{31}$ Ibidem, s. 157. 
„niewielkiej mniejszości; jest na ogół wykształcony i należy do wyższych warstw społecznych"32. Natomiast pewien anarchizm, niezbywalny w protestach przeciwko niesłusznym prawom, Arendt wywodzi z czasów, gdy sumienie było głosem Boga, zaś przykazanie „Bądź posłuszny bardziej Bogu niż ludziom”33 było „obiektywnie wiążące bez jakiegokolwiek odniesienia do instytucji ludzkich"34. Filozofka proponuje więc ścieżkę wywodzącą się od Cycerona (sumienie jako „poznawanie siebie i rozmowa ze sobą"), nawet jeśli jest to działanie, które naraża nas na kłopoty. Zachęca przy tym do rozszerzenia modelu Thoreau (jednostka sprzeciwia się systemowej „maszynie”) na działanie zbiorowe o znaczeniu politycznym, kiedy to „pewna liczba sumień będzie współbrzmieć, a protestujący w imię sumienia zdecydują się wkroczyć na rynek i dać się słyszeć publicznie" ${ }^{\prime 35}$. Należy jednak ostrzec, iż tak potraktowane sumienie zostaje „urynkowione". Przyjemność z samoanalizy i dialogu ze sobą kończy się w momencie, gdy - jak pisze Arendt - sumienie staje się „opinią, niemożliwą do odróżnienia od innych opinii [...]. A siła opinii nie zależy od sumienia, lecz od liczebności tych, którzy ją wyznają" ${ }^{\prime 36}$. Jest to konkluzja dająca nadzieję i jednocześnie gorzka.

\section{Jak rozmontować polski ruch antymyśliwski}

Wiosną, 16 kwietnia 2020 roku, pod osłoną pandemii (niczym $\mathrm{w}$ rekonstrukcji historycznej stanu wojennego złożyły się na nią zakaz gromadzenia się, zakaz protestów, kontrole policyjne samochodów, mandaty wystawiane za bieganie i jazdę na rowerze bez uzasadnienia) ${ }^{37}$ przekazano do prac w komisjach sejmowych kilka ustaw jednocześnie: dotyczącą mienia bezdziedzicznego (aby Żydzi nie mogli się już dłużej dopominać), dotyczącą zakazu edukacji seksualnej (została skierowana do prac w komisji nadzwyczajnej) oraz dotyczącą całkowitego zakazu aborcji (wykluczającego jakie-

32 Ibidem, s. 158.

${ }^{33}$ Ibidem.

${ }^{34}$ Ibidem, s. 159.

35 Ibidem, s. 161.

${ }^{36}$ Ibidem.

37 Por. Prof. Simon: Nie rozumiem prześladowania ludzi za bieganie czy rower. Niech założa maski i się ruszają. „Wprost”, 9 kwietnia 2020. https://www.wprost. $\mathrm{pl} / \mathrm{kraj} / 10313688 /$ prof-simon-nie-rozumiem-przesladowania-ludzi-za-bieganieczy-rower-niech-zaloza-maski-i-sie-ruszaja.html?fbclid=IwAR2GOZeXEP-JpifD b19piZeDcUYJkJJ6vJjO6mYC6q3Bl2TMbLmaSJodOoU [dostęp: 10.07.2020]. 
kolwiek wyjątki). Nie zapomniano także o poprawkach do prawa łowieckiego ${ }^{38}$. Dotyczyły one udziału dzieci w polowaniach. Punkt ten został skierowany do prac $\mathrm{w}$ komisji parlamentarnej przy dość licznym wsparciu (bądź nie dość licznym oporze) posłów i posłanek opozycji $i^{39}$.

Od jesieni 2018 roku odbywające się co weekend leśne spacery stały się szansą dla osób pragnących brać udział w tworzeniu pewnej ruchomej utopii, w budowaniu świata nieosadzającego się na przemocy. Zyskiwały poparcie zwykłych, lecz niechętnych myślistwu obywateli, z uwagą i sympatią śledzone były przez lokalne media ${ }^{40}$. Niewątpliwie spacery te utrudniały myśliwym wykonywanie odstrzału, do którego zostali zobowiązani przez Ministerstwo Środowiska. W mediach społecznościowych, gdzie inicjowano akcje przeprowadzenia blokad, poparcie zyskiwał Ruch Antyłowiecki (z Łodzi, Poznania, Warszawy, Trójmiasta, Lublina oraz Warszawiacy Przeciwko Myśliwym - by wymienić kilka). Organizatorzy z tygodnia na tydzień doskonalili swoje metody. W użyciu były telefony, mapy i krótkofalówki. W konkurencji z terenowymi samochodami na leśnych drogach przepadały natomiast mocno zużyte samochody osobowe, poświadczając tym samym różnice $\mathrm{w}$ dochodach między fanami polowań a ich przeciwnikami.

Chociaż agresywne epizody przyciągały uwagę mediów, wydaje się, że oprócz kilku incydentów, które zostały sfilmowane i opisane, myśliwi odnosili się do swoich Doppelgänger bez widocznego gniewu.

38 Por. Posiedzenie Sejmu Rzeczypospolitej Polskiej w dniach 15 i 16 kwietnia 2020 roku oraz 10. posiedzenie Sejmu IX kadencji. https://www.sejm.gov.pl/ sejm9.nsf/transmisje.xsp?unid=02AB509B398A0463C12584C6004EAD98\&fbclid= IwAR2Ovu0jyAX56akVaW941K61rSF2gp4ZzwBlAfhzR10w7EZXgYTaO0CXe8A [dostęp: 10.07.2020].

39 Cudzysłów użyty jest dla rozróżnienia między "opozycją" sejmową a działaczami opozycji organizującej się wokół zasady nieposłuszeństwa obywatelskiego, która liczyła na to, że w jesiennych wyborach 2019 głosuje na swoich reprezentantów. Por. B. Stoczewska: Jeszcze raz o obywatelskim nieposłuszeństwie - interpretacje, spory wokót pojęcia. "Krakowskie Studia Międzynarodowe” 2017, nr 3. Jako współczesny przykład nieposłuszeństwa obywatelskiego autorka podaje działania Obywateli RP (ibidem, s. 99). https://ruj.uj.edu.pl/xmlui/ bitstream/handle/item/50323/stoczewska_jeszcze_raz_o_obywatelskim_2017. pdf?sequence=1\&isAllowed=y [dostęp: 10.07.2020].

${ }^{40}$ L. WŁodeK: "Wynocha z lasu!” Stoimy, bo kiedy tu jesteśmy, oni nie moga strzelić. Magazyn TVN24, 20 stycznia 2018. https://tvn24.pl/magazyn-tvn24/wynocha-z-lasu-stoimy-bo-kiedy-tu-jestesmy-oni-nie-moga-strzelic,136,2441 [dostęp: 10.07.2020]. 
Być może dostrzegali podobieństwo, jakiś rodzaj bliskiej, choć nie wspólnej, determinacji, a nawet obsesji. Sama byłam świadkiem, jak uczestnicy polowania powitali czekających na nich na leśnym parkingu „spacerowiczów” oklaskami. Owszem, były to oklaski ironiczne. Trudno jednak nie docenić różnicy między ironicznym aplauzem a - dajmy na to - wycelowaną w nas lufą karabinu, niszczeniem mienia lub pobiciem. Myśliwi przywykli do obecności ekologów. Była to wojna ostatecznie dość pogodna („Słowianie, my lubim sielanki..."), ale przybierała ona na wyrazistości i znaczeniu.

Cofnijmy się o dwa lata. W marcu 2018 roku, po długich debatach, do znowelizowanego prawa łowieckiego wprowadzono zmianę: „Kto wykonuje polowanie w obecności lub przy udziale dziecka do 18. roku życia - podlega grzywnie, karze ograniczenia wolności albo pozbawienia wolności do roku" (Prawo łowieckie, art. 52, ust. 4). Ta poprawka wzbudziła niezadowolenie myśliwych, zatem minister środowiska wykorzystał kruczek prawny, aby umożliwić udział dzieci (wystarczyło zmienić definicję polowania i jego regulamin $)^{41}$. Tuż po parlamentarnych wyborach, 31 października 2019 roku, Komitet Inicjatywy Ustawodawczej „Krzewienie Tradycji Łowieckiej" złożył projekt zmiany prawa łowieckiego, uzasadniając, iż wspomniany zakaz „kłóci się z wieloletnią tradycją łowiecką, w której dzieci od najmłodszych lat brały udział w polowaniach, zainteresowane pasjami rodziców"42.

W nowym parlamentarnym rozdaniu, w listopadzie 2019 roku, przewodniczącą Komisji ds. Komisji Ochrony Środowiska, Zasobów Naturalnych i Leśnictwa została Urszula Pasławska z PSL, myśliwa, zwolenniczka udziału dzieci w polowaniach oraz hodowli futerkowej ${ }^{43}$. Podczas głosowania zyskała poparcie wszystkich posłów Koalicji Obywalskiej w tym całej Lewicy i trojga posłów

${ }^{41}$ Minister Środowiska pod dyktando myśliwych wysyła dzieci na polowanie. Pracownia na rzecz Wszystkich Istot. Aktualności, 25 września 2019. https://pra cownia.org.pl/pracownia-aktualnosci/476-minister-srodowiska-pod-dyktandomysliwych-wysyla-dzieci-na-polowanie [dostęp: 10.07.2020].

${ }^{42}$ Polowanie z dziećmi - lekcja życia czy okrutna tradycja? Kontrowersyjna akcja promocyjna [ankieta]. https://esopot.pl/pl/11_wiadomosci/4453_polowanie-zdziecmi--lekcja-zycia-czy-okrutna-tradycja-kontrowersyjna-akcja-promocyjnaankieta-.html [dostęp: 10.07.2020].

${ }^{43} \mathrm{Na}$ temat hodowli zwierząt futerkowych zob. J. PoDGórski: Zwierzęta futerkowe, a sprawa polska - czyli dlaczego minister Ardanowski ma rację? „Świat Rolnika", 19 lipca 2018. https://swiatrolnika.info/zwierzeta-futerkowe-a-prawa-polskaczyli-dlaczego-minister-ardanowski-ma-racje [dostęp: 10.07.2020]. 
Zielonych, bo posłowie i posłanki na czas się "nie zorientowali"44. Do tego oszołomiło ich, że Komisją Polityki Społecznej i Rodziny miała kierować Magdalena Biejat z klubu Lewicy, więc uznali, że po takim sukcesie komisję środowiska mogą pominaćc. Tymczasem to, co łatwo przychodzi, łatwo może zostać odebrane; Biejat została odwołana z funkcji przewodniczącej już 16 stycznia 2020 roku $^{45}$. Jak w opowiastce umoralniającej, kiedy zabraknie sumienia w charakterze busoli, choćby tego postmodernistycznego melanżu tożsamości i idealizmu, kiedy brakuje działania con scientia, to zostaje koniunkturalizm, a początkujący gracze łatwo mogą zostać ograni do nitki przez tych bardziej szczwanych.

Jako że święta Bożego Narodzenia to tradycyjny moment na słowa pojednania, 25 grudnia 2019 roku „ekologizm” został potępiony przez arcybiskupa Krakowa Marka Jędraszewskiego (który niczym czujny barometr rejestruje i wyprzedza wszelkie rządowe posunięcia) i uznany za „nową totalitarną ideologię" ${ }^{\prime 46}$, wyrastającą „przede wszystkim z negacji natury"47. Kilka dni wcześniej, 20 grudnia, przyjęta została przez sejm - także przy wsparciu posłów „opozycji"48 - specustawa zakazująca utrudniania polowań. Ustawa

44 A. Szczęśniak: Zieloni: Nie wiedzieliśmy, kim jest przewodnicząca komisji środowiska. OKO.press, 18 listopada 2019. https://oko.press/mysliwa-szefowa-komisjiochrony-srodowiska/ [dostęp: 10.07.2020].

${ }^{45}$ Magdalena Biejat odwotana $z$ funkcji przewodniczacej sejmowej komisji rodziny. TVP Info, 16 stycznia 2020. https://www.tvp.info/46223507/magdalenabiejat-odwolana-z-funkcji-przewodniczacej-sejmowej-komisji-rodziny [dostęp: 10.07.2020].

46 "Ekologizm is very dangerous and contrary to the Bible", warns Polish archbishop. „Notes from Poland”, 27 grudnia 2019. https://notesfrompoland.com/2019/12/27/ ecologism-is-very-dangerous-and-contrary-to-the-bible-says-archbishop-of-kra kow/?fbclid=IwAR1HEFGnV3pngWq1qBP7z2kC5YbyAXvsq7kD7oBzOWoHP2a sUzulRIc5Lv [dostęp: 10.07.2020].

${ }^{47}$ [Tylko u nas] ks. prof. A. Maryniarczyk: Ideologia ekologizmu, na która słusznie zwrócit uwagę ks. abp Marek Jędraszewski, wyrasta przede wszystkim z negacji natury. Radio Maryja, 27 grudnia 2019. https://www.radiomaryja.pl/informacje/tylko-u-nas-ks-prof-a-maryniarczyk-ideologia-ekologizmu-na-ktora-slusznie-zwrociluwage-ks-abp-marek-jedraszewski-wyrasta-przede-wszystkim-z-negacji-natur y/?fbclid=IwAR1h1o8w7sQkwaD1rmF946KbKNeffaPTm7AF_3goRfRAocDAL1W Z8m4f9Nk [dostęp: 10.07.2020].

48 „Z Koalicji Obywatelskiej ustawę poparł Jakub Rutnicki. Wstrzymali się: Eugeniusz Czykwin, Elżbieta Gelert, Katarzyna Osos, Paweł Poncyljusz, Jacek Protas, Marta Wcisło. Z Lewicy za ustawą byli: Romuald Ajchler, Wiesław Szczepański i Tadeusz Tomaszewski. Wstrzymał się Marek Dyduch". D. Uhuıg: 
ta następnie przeszła bez poprawek przez senat, właściwie trudno pojąć, dlaczego. Do końca bowiem nieustalone zostaje, na czym owe utrudnianie polowań miałoby polegać. Czy może to być spacer albo zbieranie grzybów? Czy też, aby zasłużyć na trzy lata więzienia, należałoby wykazać się większą aktywnością, np. wyrwać broń myśliwemu? Celowo lub przypadkiem zablokować samochód myśliwych na leśnej drodze? Zasłonić własnym ciałem ranne zwierzę? A co z przypadkowymi spacerowiczami, którzy mogą się natknąć na polowanie $z$ tłumikiem i mieć do wyboru aresztowanie albo postrzelenie ${ }^{29}$ Tymczasem ustawa przewiduje zaledwie grzywnę dla myśliwych niezachowujących zasad bioasekuracji, co zaskakuje, tym bardziej że została wprowadzona w związku z zagrożeniem ASF.

Ustawa zyskała etykietkę "pilne" na mocy uzasadnienia, że dziki roznoszą afrykański pomór świń. Jej treść nie dotyczyła jednakże tylko odstrzałów sanitarnych (te były już ujęte w prawie myśliwskim), lecz odnosiła się do wszelkiej działalności myśliwych. Nie przeszkodziły komisji sejmowej ani senatowi głosy ekspertów i statystyki potwierdzające, że rozprzestrzenianie się ASF ma wiele wspólnego z nierespektowaniem zasad bioasekuracji, które najtrudniej zachować właśnie podczas masowych polowann ${ }^{50}$. Najistotniejsza zmiana dotyczyła tego, że właściciele gruntów (czyli po prostu rolnicy) stracili możliwość dysponowania swoją własnością ziemską, akurat w czasie, gdy coraz więcej osób starało się o wyłączenie swojej ziemi z obwodów łowieckich ${ }^{51}$. Na mocy ustawy stawiający opór

Sejm za specustawa ws. ASF z zakazem utrudniania polowań. Część opozycji głosowała jak PiS. „Gazeta Wyborcza”, 20 grudnia 2019. https://sonar.wyborcza.pl/sonar/7,15 6422,25534894,specustawa-ws-asf-przyjeta-bedzie-zakaz-utrudniania-polowan. html?utm_source=facebook.com\&utm_medium=SM\&utm_campaign=FB_Ga zeta_Wyborcza\&fbclid=IwAR0sXKdTZEMmyuu95EjbDa7cTYwOPWMy9kfkIw mm_E-m80JbaE7p9EWqMjw [dostęp: 10.07.2020].

49 A. Kurzyp, B. Chyż: Śmierć na polowaniach. Gina nie tylko zwierzęta, ale również ludzie. https://biqdata.wyborcza.pl/biqdata/7,159116,25425445,mapa-wypadkowna-polowaniach-gina-nie-tylko-na-zwierzeta.html [dostęp: 10.07.2020]. Warta uwagi jest też książka Tadeusza Andrzejczaka: Wypadki na polowaniach. To nie musiało się zdarzyć. Warszawa 2010.

${ }^{50}$ „Prezydent podpisał wyrok nie tylko na dziki, ale też ekologów? Jedno jest pewne - szykuje się wielkie strzelanie”. „Bezprawnik”, 29 stycznia 2020. https://bezprawnik.pl/lex-ardanowski/ [dostęp: 10.07.2020].

${ }^{51}$ R. SківіŃsка: Walka o ziemię bez strzatów i myśliwych. „Polityka”, 29 czerwca 2019. https://www.polityka.pl/tygodnikpolityka/spoleczenstwo/1797954,1,walkao-ziemie-bez-strzalow-i-mysliwych.read [dostęp: 10.07.2020]. 
właściciel gruntu ma szansę znaleźć się w więzieniu, zaś myśliwi mają prawo zaangażować do ochrony polowania policję, strażaków i Straż Miejską. Ustawa ma więc ogromny potencjał konfliktogenny. A jeśli przyjąć, że rządzący państwem nie spodziewali się pandemii i przymusowego złagodzenia obyczajów, można wręcz suponować, że władza z pełną świadomością skutków zmierzała do zaognienia konfliktów.

W styczniu 2019 roku obrońcy praw zwierząt liczyli na veto prezydenta. Przypomnieli mu nawet obietnicę wyborczą z 22 maja 2015 roku, która brzmiała: „nie podpiszę żadnej ustawy, która by pogarszała los zwierząt i podpiszę każdą ustawę, która ten los poprawi" ${ }^{\prime 2}$. Jednak prezydent 29 stycznia 2020 roku podpisał ustawę ${ }^{53}$. Co ciekawe, być może właśnie z braku ustalenia, na czym szkodzenie polowaniom miałoby polegać, ustawa nie powstrzymała działalności obywatelskich ruchów antymyśliwskich. Przeciwnie, weekendowe spacery w lesie tym bardziej stały się deklaracją oporu w duchu nieposłuszeństwa obywatelskiego, zgodnie z mottem Henry'ego Davida Thoreau, ,Jeśli prawo jest niesprawiedliwe, złam je"54 i z gotowością do przyjęcia konsekwencji łamania prawa (amerykański transcendentalista, podobnie jak sto lat później Martin Luter King, ostrzegał, że łamiący niesprawiedliwe prawo musi brać pod uwagę to, że znajdzie się $\mathrm{w}$ więzieniu) ${ }^{55}$. Poczynając od połowy stycznia, relacje między aktywistami i myśliwymi zmieniły się w kilku miejscach Polski na napięte i agresywne (choć można było jeszcze racjonalnie liczyć na to, że senat zgłosi zastrzeżenia, a prezydent zawetuje

${ }^{52}$ A. Duda: List do wszystkich tych, którzy sa przyjaciótmi zwierzat. https://www. facebook.com/RuchAntylowieckiWielkopolska/photos/a.251191325807683/477511 779842302/?type=3\&theater [dostęp: 10.07.2020].

${ }^{53}$ K. Kojzar: Prezydent podpisat ustawe "lex Adranowski". Koniec z bezpiecznymi spacerami po lesie. „SmogLab”, 29 stycznia 2020. https://smoglab.pl/prezydent-pod pisal-ustawe-lex-adranowski-koniec-z-bezpiecznymi-spacerami-w-lesie/ [dostęp: 10.07.2020].

${ }^{54}$ H.D. Thoreau: Obywatelskie niepostuszeństwo..., s. 208. Por. tekst oryginalny "If the injustice has a spring, or a pulley, or a rope, or a crank, exclusively for itself, then perhaps you may consider whether the remedy will not be worse than the evil; but if it is of such a nature that it requires you to be the agent of injustice to another, then, I say, break the law". H.D. Thoreau: Civil disobedience. https://xroads.virginia.edu/ Hyper2/thoreau/civil.html [dostęp: 10.07.2020].

${ }_{55}$ M. UnваŃczyк: Przeciw segregacji rasowej. Idea nonviolence $i$ jej filozoficzne korzenie w myśli społecznej Martina Luthera Kinga. „Filo-Sofija” 2015, nr 29, s. 184. 
ustawę, co nie nastąpiło) ${ }^{56}$. Ten niebezpieczny rozwój sytuacji został jednak powstrzymany przez pandemię.

W połowie lutego 2020 roku wokół Diany Piotrowskiej, propagatorki udziału dzieci w polowaniach, został wywołany pewien skandal. Ona sama zaprzecza jednak, że jest autorką stwierdzeń, które jej przypisano, jak np.: „Małe dzieci powinny patrzeć na zabijanie zwierząt, bo to je kształtuje pozytywnie, osadza w realnym świecie i zabezpiecza przed homoseksualizmem"57. Memy, pod którymi wybuchały gorące dyskusje, nigdy nie wskazują daty ani miejsca. 14 marca 2020 roku Piotrowska została odznaczona przez Prezydenta Andrzeja Dudę Brązowym Krzyżem Zasługi za wkład w rozwój edukacji przyrodniczej ${ }^{58}$. Wydaje się możliwe, że była rzeczniczka PZŁ, której jedyne udokumentowane wypowiedzi potwierdzają zaledwie naiwność i myślenie życzeniowe, padła ofiarą trollingu ${ }^{59}$.

Z dokumentu Ministerstwa Środowiska z 17 października 2018 roku, do którego dotarła Pracownia na rzecz Wszystkich Istot, wynikało, że już w pierwszej wersji nowelizacji prawa łowieckiego, uzasadnianej koniecznością skuteczniejszej walki z ASF poprzez odstrzał dzików, ukryty został przepis zezwalający na udział dzieci $\mathrm{w}$ polowaniach. Ujawnienie tego faktu przez OKO.press musiało sprawić, iż obie kwestie zostały rozdzielone ${ }^{60}$. I tak, 16 kwietnia odbyło się głosowanie nad wprowadzeniem poprawki, czyli anulowaniem dwa lata wcześniej wprowadzonego art. 52, ust. 4.

${ }^{56}$ W sytuacji tu opisanej, myśliwy postanowił polować na terenie stadniny łowieckiej i wezwał policję, gdy właściciel próbował wyprosić go z działki. Myśliwy wezwat policję, powołując się na ustawę "lex Ardanowski". Onet, 17 luty 2020. https://wiadomosci.onet.pl/kraj/mysliwy-wezwal-policje-powolujac-sie-naustawe-lex-ardanowski/8v23rmb [dostęp: 10.07.2020].

${ }^{57} \mathrm{https} / / /$ swiatrolnika.info/kompromitacja-i-skandaliczne-zachowanie-mece nas-topczewskiej-z-fundacji-viva [dostęp: 10.07.2020].

${ }^{58}$ Postanowienie Prezydenta Rzeczypospolitej Polskiej z dnia 14 marca 2020 o nadawaniu odznaczeń. https://www.prawo.pl/akty/m-p-2018-576,18729870.html [dostęp: 10.07.2020].

59 Rzeczniczka myśliwych: My dokarmiamy zwierzęta. Szczuka: Bo nie mielibyście do czego strzelać. TokFM, 28 luty 2017. https://www.tokfm.pl/Tokfm/7,103454,214 31790,rzeczniczka-mysliwych-my-dokarmiamy-zwierzeta-szczuka-bo.html [dostęp: 10.07.2020].

${ }^{60}$ R. Jurszo: Dzieci na polowaniach i łowy z łukiem w miastach. Ministerstwo ukrywa prace nad zmiana prawa łowieckiego. https://oko.press/dzieci-na-polowaniach-ilowy-z-lukiem-w-miastach-ministerstwo-ukrywa-prace-nad-zmiana-prawa-lo wieckiego/?fbclid=IwAR3IzUT6Yq5WmUPV3U8Qzj_L7GFgRAsdkGUjmpDYN5aEOUhUdlnlil5e5BM [dostęp: 10.07.2020]. 
Dwanaścioro posłów i posłanek lewicy głosowało za dopuszczeniem dzieci (osób poniżej 18. roku życia) do polowań. Pytani o motywację stanowiska dawali najróżniejsze wyjaśnienia. Jedna posłanka pomyliła się. Innych być może przekonała argumentacja: „Polowanie ma nieocenione walory poznawcze. Pozwala młodym ludziom zgłębiać tajniki przyrody w sposób bezpośredni i autentyczny. Polowanie to sztuka świadomego podejmowania wyborów"61. Poseł Szczepański zadziwił deklaracją, że z zasady nie odrzuca projektów obywatelskich (tymczasem pomysłodawcą zmiany w ustawie był Komitet Inicjatywy Ustawodawczej „Krzewienie Tradycji Łowieckiej”, którego pełnomocnikiem jest Rafał Malec, prezes Naczelnej Rady Łowieckiej PZŁ). Ktoś inny twierdził nieprawdziwie, że w żadnym innym europejskim kraju nie obowiązują podobne zakazy. Trudno tu mówić o działaniu con scientia, zgodnie z wiedzą. A przecież literatura jest dostępna. Problemem przyuczania do przemocy przez polowanie (do czerpania radości z zabijania, ocenianego przez autora jako zjawisko negatywne) zajmuje się Andrzej Elżanowski, pisząc m.in.: „Łowiectwo brutalizuje społeczeństwo szczególnie przez wychowanie dzieci, którym rodzice ustawiają mózgowy układ nagrody na radość z zabijania, zanim dzieci staną się zdolne do własnej oceny moralnej" ${ }^{\prime 2}$. Zarazem Elżanowski odnotowuje, jak zmienia się, nie

${ }^{61}$ T. NyczKa: "Łowiectwo może stać się pasja dziecka”. Posłowie Lewicy zagłosowali tak jak PiS. „Gazeta Wyborcza”, 17 kwietnia 2020. https://poznan.wyborcza. pl/poznan/7,36001,25877188,lowiectwo-moze-stac-sie-pasja-dziecka-poslowie-zlewicy-zaglosowali.html [dostęp: 10.07.2020]. W sumie na przełomie 2019-2010 roku odbyły się trzy głosowania, ograniczające siłę protestów obywatelskich przeciwko myśliwym i polowaniom, które z końcem 2019 roku były o krok od tego, żeby zmienić się w ruch krajowy. Głosowanie z 16 kwietnia 2020 roku było trzecim z kolei. Projekt udziału dzieci w polowaniach poparli: Romuald Ajchler, Jacer Czerniak, Arkadiusz Iwaniak, Marcin Kulasek, Robert Kwiatkowski, Małgorzata Sekuła-Szmajdzińska, Wiesław Szczepański, Andrzej Szejna, Jan Szopiński, Tadeusz Tomaszewski, Katarzyna Ueberhan (zgłoszona pomyłka), Bogusław Wontor. Por. Sejm IX kadencji, aktualni posłowie. https://www. sejm.gov.pl/Sejm9.nsf/poslowie.xsp?type=A [dostęp: 10.07.2020].

62 A. Elżanowsкr: Motywacja i moralność łowiecka. „Zoophilologica. Polish Journal of Animal Studies” 2018, nr 4, s. 123. Co ciekawe, „Asz Dziennik” także podkreślił element edukacyjny w prześmiewczym artykule: „Polowania będą dostosowane do wieku dzieci - zapewnia nas pan Jędrzej, myśliwy z koła łowieckiego". „Zagajnik z Podlasia. - Młode koźlęta nie nauczyły się jeszcze szybkiego biegu, więc będą łatwym celem nawet dla debiutujących strzelców". Zob. "Myśliwi obiecuja: przy matych dzieciach będa strzelać tylko do małych sarenek”. „Asz Dziennik”, 16 kwietnia 2020. https://aszdziennik.pl/129273,mysliwi- 
tylko w Polsce, nasza wrażliwość, zwraca uwagę, że zachowania okrutne wobec zwierząt, wcześniej tolerowane lub niezauważane, dziś wzbudzają niepokój i niezgodę.

Jeszcze w połowie kwietnia 2020 roku głosy przedstawicieli ruchu antyłowieckiego były na tyle silne, że wraz z wypowiedziami myśliwych, argumentujących, iż mają prawo wychowywać dzieci „według własnych poglądów", media cytują oświadczenie Łódzkiego Ruchu Antyłowieckiego:

[...] myśliwi pragną złamać kruchą psychikę dzieci, ucząc je okrucieństwa, zadawania bólu i śmierci, osłabiając w nich naturalną umiejętność rozpoznawania zła. Podczas gdy w trosce o rozwój dzieci telewizje muszą oznaczać programy zawierające brutalne sceny, myśliwi chcą je pokazywać z bliska, zabierając najmłodszych ze sobą na polowanie ${ }^{63}$.

Te i inne argumenty przez ostatnie dwa lata były cytowane i przytaczane. Ich manifestacyjna wręcz nieznajomość $\mathrm{w}$ wydaniu posłów „opozycji”, w połączeniu z brakiem wspólnej bazy etycznej wywołuje zdumienie. Dla kontrastu, politycy Konfederacji Wolność i Niepodległość przedstawiają zbiór argumentów umocowany $\mathrm{w}$ tradycji, która nie jest tradycją XIX-wiecznych pionierów ekologii $^{64}$. W sporze o obecność dzieci na polowaniach chodzi bowiem

obiecuja-przy-dzieciach-beda-strzelac-tylko-do-malych-zwierzatek?fbclid=IwA R2hqB8mpReWwsTn1-vg8ouzzJPY3LMWz44r_mGi3KI8ZJ6u_RMui-q-Kw4 [dostęp: 10.07.2020]. Por. także F. Łoвodzińsкi: Obłudni z piórkiem. „Newsweek”, 3 listopada 2018. https://www.newsweek.pl/polska/odrazajacy-obludni-z-piorkiem/ hm7ezxe?fbclid=IwAR3w6GZvgnW8IBDmxJsvS_YyQiIqrSSD0NtRAYjySycO vvZfS9JLGiDKkME [dostęp: 10.07.2020].

${ }^{63}$ B. Rogowska: Łódzcy myśliwi: "Zieloni chca nam narzucić, jak mamy wychowywać dzieci". https://lodz.wyborcza.pl/lodz/7,35136,25867258,sejm-zaglosuje-wsprawie-udzialu-dzieci-w-polowaniach-lodzcy.html?fbclid=IwAR1_jQlkrrLJ 2Z-ye-1C6A8To1wrLXaI8IsyA0CH1FHyIq-vh18sh97741Y [dostęp: 10.07.2020]. Por. oświadczenie Łódzkiego Ruchu Antyłowieckiego: „Zanurzenie dzieci w »kulturze łowieckiej« niczego ich nie nauczy - wystawienie na krwawe obrazy, oswajanie z cierpieniem drugiej istoty i zadawaniem jej śmierci nie jest ani pedagogiczne, ani normalne. Jest demoralizujące i niezgodne z prawem dziecka do bezpiecznego dzieciństwa i rozwoju emocjonalnego, gwarantującego dorosłość bez przemocy". https://www.facebook.com/LodzkiRuchAntylowiecki/ photos/a.215707705640403/648863092324860/?type=3\&theater [dostęp: 10.07.2020].

${ }^{64}$ W. Czuchnowski: PIS i Konfederacja za dopuszczeniem dzieci do polowań. „Gazeta Wyborcza", 15 kwietnia 2020. https://wyborcza.pl/7,75398,25872338,dziecina-polowaniach-pis-jest-za.html [dostęp: 10.07.2020]. 
o edukację. "Opozycji” zabrakło więc alternatywnej propozycji edukacyjnej, która mogłaby się stać jej programem, takiego zatem wychowania, które ograniczało element czerpania korzyści z cudzej krzywdy, a zwiększało empatię.

W antologii-manifeście Etyczne potępienie myślistwa (gdzie rozliczni autorzy uzupełniają swoją akademicką afiliację o przynależność do Akademickiego Stowarzyszenia Przeciwko Myślistwu Rekreacyjnemu) Beata Kulisiewicz podkreśla, iż „Dziecko nie rodzi się przecież z sumieniem regulującym kontakty z otoczeniem ${ }^{\prime \prime 5}$. Dziecko uczy się przez naśladowanie, jak i też $\mathrm{z}$ obawy przed karą (którą może być hipotetyczna utrata miłości), że nie wolno męczyć zwierząt ani bić innych dzieci: „Zanim dziecko wytworzy własne, autonomiczne sumienie, musi upłynąć parę lat"66. Zakładając, że myśliwi, tak samo jak inni rodzice, chcą mieć dobre dzieci, które następnie wyrosną na dobrych ludzi, pisze Kulisiewicz, można dostrzec tu zaczyn wewnętrznego konfliktu dziecka, które przygląda się bądź uczestniczy w zwierzęcej agonii, ciągnięciu bądź dobijaniu konających zwierząt, by następnie spoglądać na radość dorosłych, kontrastującą z gwałtowną śmiercią, ludzką rywalizację i dumę, ucztę zwycięzców, wspólne fotografowanie się i śpiewy ${ }^{67}$.

Jakie zatem praktyczne umiejętności dziecko na polowaniu ma szansę posiąść? Przede wszystkim, dążąc do akceptacji, zaskarbienia sobie uwagi rodzica, uczy się tłumić ledwo wykształcające się współczucie (które sprawia, że dziecko płacze po stracie ukochanego domowego zwierzątka), tłumi zdolność do empatii, a być może również traci szansę na obiektywne postrzeganie dobra. Gdyż ta nieznośna relatywność sumienia, o której pisze Arendt, za której sprawą mój sąsiad i ja będziemy postępować $\mathrm{w}$ zgodzie $\mathrm{z}$ naszym sumieniem, dokonując kompletnie różnych wyborów, kryje w sobie założenie, że oboje - ja i sąsiad - dysponujemy na równi wykształconym pragnieniem postępowania dobrze, a zmienić opinię możemy w rezultacie dyskusji (rozumowego argumentu) lub na fali współczucia (adekwatnego przykładu). Lecz kiedy ulegamy, nie chcąc sprawiać kłopotu lub identyfikujemy się ze sprawcami przemocy, bo tak nas wychowano, to już nie ma nic wspólnego z sumieniem.

65 B. Kulisiewicz: Prawne, psychologiczne i etyczne konteksty udziału dzieci w polowaniach. W: Etyczne potępienie myślistwa. Red. D. Probucka. Kraków 2020, s. 173.

${ }^{66}$ Ibidem, s. 172.

${ }^{67}$ Ibidem, s. 176. 


\section{Bibliografia}

38\% Polaków czyta ksiażki. https://www.bn.org.pl/w-bibliotece/3413-38\%25polakow-czyta-ksiazki.html [dostęp: 15.07.2020].

American Conservationism Timeline.https://www.nps.gov/mabi/learn/historyculture/ conservation-timeline-1801-1900.htm [dostęp: 24.09.2020].

Andrzejczak T.: Wypadki na polowaniach. To nie musiało się zdarzyć. Warszawa 2010.

Arendt H.: O przemocy. Niepostuszeństwo obywatelskie. Przeł. A. Łagodzka, W. Madej. Warszawa 1999.

Czuchnowski W.: PiS i Konfederacja za dopuszczeniem dzieci do polowań. „Gazeta Wyborcza", 15 kwietnia 2020. https://wyborcza.pl/7,75398,25872338,dzieci-napolowaniach-pis-jest-za.html [dostęp: 10.07.2020].

DudA A.: List do wszystkich tych, którzy sa przyjaciótmi zwierząt. https://www. facebook.com/RuchAntylowieckiWielkopolska/photos/a.251191325807683/47 7511779842302/?type=3\&theater [dostęp: 10.07.2020].

Dutton K.: Mądrość psychopatów. Lekcja życia pobrana od świętych, szpiegów i seryjnych morderców. Przeł. M. Wyrwas-Wiśniewska. Warszawa 2014.

"Ekologizm is very dangerous and contrary to the Bible", warns Polish archbishop. „Notes from Poland”, 27 grudnia 2019. https://notesfrompoland. com/2019/12/27/ecologism-is-very-dangerous-and-contrary-to-the-bible-saysarchbishop-of-krakow/?fbclid=IwAR1HEFGnV3pngWq1qBP7z2kC5YbyAXvs q7kD7oBzOWoHP2asUzulRIc5Lv8 [dostęp: 10.07.2020].

ElżAnowski A.: Motywacja i moralność łowiecka. „Zoophilologica. Polish Journal of Animal Studies" 2018, nr 4, s. 121-191.

Etyczne potępienie myślistwa. Red. D. Probucka. Kraków 2020.

Historia kultury materialnej Polski. T. 5: Od 1795 do 1870 roku. Red. W. Hensel, J. Pazdura. Wrocław 1978.

Jurszo R.: Dzieci na polowaniach $i$ łowy z łukiem w miastach. Ministerstwo ukrywa prace nad zmiana prawa towieckiego. https://oko.press/dzieci-na-polowaniach-ilo wy-z-lukiem-w-miastach-ministerstwo-ukrywa-prace-nad-zmiana-prawalowieckiego/?fbclid=IwAR3IzUT6Yq5WmUPV3U8Qzj_L7GFgRAsdkGUjm pDYN5aEOUhUdlnli15e5BM [dostęp: 10.07.2020].

Kojzar K.: Prezydent podpisat ustawe „lex Adranowski”. Koniec z bezpiecznymi spacerami po lesie. „SmogLab”, 29 stycznia 2020. https://smoglab.pl/prezydent-pod pisal-ustawe-lex-adranowski-koniec-z-bezpiecznymi-spacerami-w-lesie/ [dostęp: 10.07.2020].

Kolbuszewski J.: Ochrona przyrody a kultura. Warszawa 1990.

Koonz C.: How the Nazis Made Anti-Semitism Respectable. https://www.youtube. com/watch?v=usL9bmrnQRk [dostęp: 12.07.2020].

Koonz C.: The Nazi Conscience. Cambridge 2003.

Kossak S.: Saga Puszczy Białowieskiej. Warszawa 2016.

Kulisiewicz B.: Prawne, psychologiczne i etyczne konteksty udziału dzieci w polowaniach. W: Etyczne potępienie myślistwa. Red. D. Proвucka. Kraków 2020, s. $163-178$. 
Kurzyp A., Chyż B.: Śmierć na polowaniach. Gina nie tylko zwierzęta, ale również ludzie. https://biqdata.wyborcza.pl/biqdata/7,159116,25425445,mapa-wypadkowna-polowaniach-gina-nie-tylko-na-zwierzeta.html [dostęp: 10.07.2020].

Leszczyński A.: Ludowa historia Polski. Warszawa 2020.

Łoвodzıńsкi F.: Obłudni z piórkiem. „Newsweek”, 3 listopada 2018. https://www. newsweek.pl/polska/odrazajacy-obludni-z-piorkiem/hm7ezxe?fbclid=IwA R3w6GZvgnW8IBDmxJsvS_YyQiIqrSSD0NtRAYjySycOvvZfS9JLGiDKkME [dostęp: 10.07.2020]

Magdalena Biejat odwołana z funkcji przewodniczacej sejmowej komisji rodziny. TVP Info, 16 stycznia 2020. https://www.tvp.info/46223507/magdalena-biejat-odwola na-z-funkcji-przewodniczacej-sejmowej-komisji-rodziny [dostęp: 10.07.2020].

Minister Środowiska pod dyktando myśliwych wysyła dzieci na polowanie. Pracownia na rzecz Wszystkich Istot. Aktualności, 25 września 2019. https://pracownia. org.pl/pracownia-aktualnosci/476-minister-srodowiska-pod-dyktando-my sliwych-wysyla-dzieci-na-polowanie [dostęp: 10.07.2020].

Мүтүсн B.: Poetyka $i$ łowy. O idei dawnego polowania w literaturze polskiej XIX wieku. Katowice 2004.

Nyczka T.: "Łowiectwo może stać się pasja dziecka”. Posłowie Lewicy zagłosowali tak jak PiS. „Gazeta Wyborcza”, 17 kwietnia 2020. https://poznan.wyborcza.pl/ poznan/7,36001,25877188,lowiectwo-moze-stac-sie-pasja-dziecka-poslowie-zlewicy-zaglosowali.html [dostęp: 10.07.2020].

PoDgórski J.: Zwierzęta futerkowe, a sprawa polska - czyli dlaczego minister Ardanowski ma rację? "Świat Rolnika”, 19 lipca 2018. https://swiatrolnika.info/ zwierzeta-futerkowe-a-sprawa-polska-czyli-dlaczego-minister-ardanowskima-racje [dostęp: 10.07.2020].

Polowanie z dziećmi - lekcja życia czy okrutna tradycja? Kontrowersyjna akcja promocyjna [ankieta]. https://esopot.pl/pl/11_wiadomosci/4453_polowanie-z-dziecmi ---lekcja-zycia-czy-okrutna-tradycja-kontrowersyjna-akcja-promocyjnaankieta-.html [dostęp: 10.07.2020].

Posiedzenie Sejmu Rzeczypospolitej Polskiej w dniach 15 i 16 kwietnia 2020 roku oraz 10. posiedzenie Sejmu IX kadencji. https://www.sejm.gov.pl/sejm9. nsf/transmisje.xsp?unid=02AB509B398A0463C12584C6004EAD98\&fbclid=Iw AR2Ovu0jyjAx56akVaW941K61rSF2gp4ZzwB1AfhzR10wEZXg taO0CXe8A [dostęp: 10.07.2020].

Praktyka - utopia - metafora. Wynalazek w XIX wieku. Red. J. КuвicкA, M. Liтwinowicz-DroździeL. Warszawa 2016.

Prof. Simon: Nie rozumiem prześladowania ludzi za bieganie czy rower. Niech założa maski i się ruszają. „Wprost”, 9 kwietnia 2020. https://www.wprost.pl/ kraj/10313688/prof-simon-nie-rozumiem-przesladowania-ludzi-za-bieganieczy-rower-niech-zaloza-maski-i-sie-ruszaja.html?fbclid=IwAR2GOZeXEP-JpifDb19piZeDcUYJkJJ6vJjO6mYC6q3Bl2TMbLmaSJodOoU [dostęp: 10.07.2020].

Rogowska B.: Łódzcy myśliwi: "Zieloni chca nam narzucić, jak mamy wychowywać dzieci". https://lodz.wyborcza.pl/lodz/7,35136,25867258,sejm-zaglosuje-w-spra wie-udzialu-dzieci-w-polowaniach-lodzcy.html?fbclid=IwAR1_jQlkrrLJ2Zye-1C6A8To1wrLXaI8IsyA0CH1FHyIq-vh18sh97741Y [dostęp: 10.07.2020]. 
Rok 1939 w dzienniku Hansa Franka. Przeł. W. Grotowicz. Wstęp i oprac. P. KosińsKi. Warszawa 2019.

SківіŃsка R.: Walka o ziemię bez strzałów i myśliwych. „Polityka”, 29 czerwca 2019. https://www.polityka.pl/tygodnikpolityka/spoleczenstwo/1797954,1,walka-oziemie-bez-strzalow-i-mysliwych.read [dostęp: 10.07.2020].

Stoczewsкa B.: Jeszcze raz o obywatelskim nieposłuszeństwie - interpretacje. Spory wokót pojęcia. „Krakowskie Studia Międzynarodowe” 2017, nr 3, s. 83-99.

Szafer W.: Tatrzański Park Narodowy. Kraków 1962.

SzczęŚniaK A.: Zieloni: Nie wiedzieliśmy, kim jest przewodnicząca komisji środowiska. OKO.press, 18 listopada 2019. https://oko.press/zieloni-nie-wiedzielismy-kimjest-przewodniczaca-komisji-srodowiska/ [dostęp: 10.07.2020].

Thoreau H.D.: Obywatelskie niepostuszeństwo. W: Inem: Życie bez zasad: eseje. Wybrała, przeł., przedmową i przypisami opatrzyła H. Cieplińska. Warszawa 1983, s. 197-229.

Tokarz W.: Dzieje Polski: 1816-1831. Warszawa 1930.

Torat Chowot ha-Lewawot (Nauka obowiazków serca). https://www.jhi.pl/psj/Ba chia_ben_Josef_ibn_Pakuda_(Bakoda) [dostęp: 12.07.2020].

[Tylko u nas] ks. prof. A. Maryniarczyk: Ideologia ekologizmu, na która stusznie zwrócit uwage ks. abp Marek Jędraszewski, wyrasta przede wszystkim z negacji natury. Radio Maryja, 27 grudnia 2019. https://www.radiomaryja.pl/informacje/ tylko-u-nas-ks-prof-a-maryniarczyk-ideologia-ekologizmu-na-ktora-slusz nie-zwrocil-uwage-ks-abp-marek-jedraszewski-wyrasta--przede-wszystkim -z-negacji-natury/?fbclid=IwAR1h1o8w7sQkwaD1rmF946KbKNeffaPTm7AF_ 3goRfRAocDAL1WZ8m4f9Nk [dostęp: 10.07.2020].

Uhlig D.: Sejm za specustawa ws. ASF z zakazem utrudniania polowań. Czesść opozycji głosowała jak PiS. „Gazeta Wyborcza”, 20 grudnia 2019. https:// sonar.wyborcza.pl/sonar/7,156422,25534894,specustawa-ws-asf-przyjeta-be dzie-zakaz-utrudniania-polowan.html?utm_source=facebook.com\&utm medium=SM\&utm_campaign=FB_Gazeta_Wyborcza\&fbclid=IwAR0sXK dTZEMmyuu95EjbDa7cTYwOPWMy9kfkIwmm_E-m80JbaE7p9EWqMjw [dostęp: 10.07.2020].

Urbańczyк M.: Przeciw segregacji rasowej. Idea nonviolence i jej filozoficzne korzenie w myśli społecznej Martina Luthera Kinga. „Filo-Sofija” 2015, nr 29, s. 177-191.

Wajrak A.: "Polska rżnie lasy, aż wióry leca". „Gazeta Wyborcza”, 7 lipca 2020. https://wyborcza.pl/7,75400,26104840,polska-rznie-lasy-az-wiory-leca.html [dostęp: 10.07.2020].

WŁodeк L.: „Wynocha z lasu!” Stoimy, bo kiedy tu jesteśmy, oni nie moga strzelić. „Magazyn TVN24”, 20 stycznia 2018.

Izabela Morska - wykładowczyni w Instytucie Anglistyki i Amerykanistyki Uniwersytetu Gdańskiego. Jest autorką około dziesięciu książek, na które składają się zbiory poezji, fragmenty teatralne, proza i eseistyka. W lutym 2017 roku uzyskała stopień doktora habilitowanego nauk humanistycznych na pod- 
stawie rozprawy Glorious Outlaws (Wspaniali wygnańcy), traktującej o tym, jak dług motywuje decyzje bohaterów we współczesnej prozie światowej. W 2018 roku otrzymała Nagrodę Literacką imienia Juliana Tuwima za całokształt twórczości. W 2020 roku jej książka - dziennik z choroby - Znikanie, otrzymała Pomorską Nagrodę Literacką „Wiatr od morza”. Kieruje Pracownią Badań nad Kulturą i Literaturą Żydowską na Wydziale Filologicznym UG i współpracuje ze Stowarzyszeniem na rzecz Osób LGBT Tolerado. Ma za sobą przeszło 50 konferencji i festiwali; najnowsze spotkania, panele dyskusyjne i podcasty są dostępne pod adresem: https://morska.net/appearances/.

e-mail: izabela.morska@ug.edu.pl 